\title{
TRADITIONAL LANGUAGE TEACHING VERSUS ICT- ORIENTED CLASSROOM
}

\author{
Maja Veljković Michos*, \\ Katarina Nasradin, \\ Valentina Bošković Marković
}

Singidunum University,

Belgrade, Serbia

\section{Correspondence:}

Maja Veljković Michos

e-mail:

mveljkovic@singidunum.ac.rs

\begin{abstract}
:
The 21 st century classroom is, with the necessary infrastructure, an environment much more developed than the traditional classroom. Since the purpose of a language is communication between people, both written and oral, the Internet has become an extraordinary resource for teaching and learning a foreign language. The Information and Communication Technologies (ICT) make it possible to accelerate the teaching and learning process, as they help students learn from a distance. In other words, they are an effective, fast and cheap way to acquire a new language, which is why it is gaining more or more attention. Nevertheless, traditional classroom still exists and functions with very effective results. The research conducted for the purpose of this paper shows how students perceive and evaluate both traditional and ICT supported learning of a foreign language in higher education environment, with the aim of discovering which of the two approaches students find more suitable for learning a foreign language.
\end{abstract}

Keywords:

Foreign language learning, traditional classroom, Internet, ICT.

\section{INTRODUCTION}

Education has experienced significant changes in recent years due to technological advancements. Language teaching, as a specific branch of education, has experienced these changes as well. Foreign language teachers tend to use the latest methodological trends, and they do their best to be well-informed regarding everything that educational technology can provide in their field.

At the same time, our students, as digital natives, live in fast and changing environment, with many possibilities and answers accessible by using the Internet and new technologies.

The role of teachers and students has experienced important changes during the digital age. In comparison with the traditional classroom where the teacher was a central figure, as someone who is both a leader and the main source of knowledge and information, whereas students were mostly receivers of the educational contents provided by teachers and textbooks, nowadays, students play the main role in the teaching and learning process. The teacher's role has transformed from traditional 
figure of teacher-educator to the new role of moderator, facilitator, and instructor. The learners have become the very active participants and responsible protagonists in the teaching-learning process. Moreover, the learning environment has also changed. The students of today can choose not only how to learn, access and share information, but where and when to learn. The learning experience has been changed with the use of ICT, breaking the barriers of time and space (e-learning).

Therefore, new generations of teachers should be skilled to select, update and use knowledge in a specific context, and to be able to adapt their knowledge to new, changeable situations [1].

However, the question is if the ICT are always effective for language teaching and learning. Another relevant question is whether we use these new resources properly, as well as whether we as teachers really have all the necessary tools to achieve effective learning at our disposal. Furthermore, do our students always expect their teachers to use ICT tools in the classroom? What is the opinion of our students regarding the way they learn a foreign language and the resources that are used in their language classrooms? That is why we have decided to understand how our students perceive and evaluate both traditional and ICT supported learning of a foreign language.

\section{ICT IN THE CLASSROOM}

The presence of ICT (information and communications technology) or LTK (language tool kit) in foreign language teaching has become essential in order to satisfy the demands of modern education contexts of Information and Knowledge society [2]. The new digital skills of teachers of a foreign language are required and indispensable, mainly those related to the creation and adaptation of digital materials, communication activities in digital media, as well as the implementation of digital strategies for learning a foreign language, such as autonomy or evaluation. We agree with Zabalza [3] regarding necessary skills and professional teacher's competences, in order to achieve effective teaching:

1. Planning the teaching-learning process,

2. Selecting and preparing the course contents,

3. Offering understandable and well-organized information and explanations (communicative competence),

4. Using new technologies,
5. Designing the methodology and organizing class activities (Organization of space; Methods selection; Selection and creation of activities),

6. Communication with students,

7. Mentoring,

8. Evaluating,

9. Educational research,

10. Identifying with the institution and team- work skills.

As stated above, the fourth skill refers explicitly to new technologies, and nine other teachers' competences are applicable to 'pre-digital' era as well. As professionals of the digital society, language teachers definitely need to know how to search, select and distinguish relevant information as fresh, updated teaching material and how to use and apply the three essential elements of new technologies (ICT) in their classroom: 1. Devices (smartphones, tablets, etc.); 2. Applications (Google Play Store, appStore, Office, multimedia, and many others), and 3. Web.

We relate those ICT elements with concepts of motivation and familiarity of their users - students, who also have expectations about their way of learning.

For that reason, and despite benefits of the Internet and adaptation to the new digitalized context, it is also important to mention that ICT have drawbacks:

- Loss of time: teachers and students need time to find proper and updated information within amounts of unreliable information;

- The Internet is a privilege for the user but it also implies a responsibility, and digital courtesy or netiquette ${ }^{1}$;

- The interest of students can be distracted to other contents than those planned by the teacher;

- Students' motivation can be lost if they spend much time searching, reading and interpreting different contents, assigned by teacher, which can cause disorientation and cognitive overload;

- Regarding language skills, the gap between oral and written skills can cause negative feedback.

\section{TRADITIONAL CLASSROOM}

The sheer term "traditional classroom" gives away the idea of it being very different than modern, well-equipped

1 Rules of behavior, good manners or moral practice and norms in digital environment and virtual interactions, Rinaldi (1997) [4]. 
clasroom of contemporary society. If we compare the classroom of the past and a contemporary classroom, we might conclude that the main components are tables, board, and a marker/ chalk, along with the teacher and his/her desk. The modern classroom has sounding system, a computer, projector and very often an interactive whiteboard. A classroom has students and a teacher, as that is its main purpose from its creation. If we analyze the teaching methods regarding foreign languages, grammar- translation method was most often used in the past. It later transformed into communicative method, and today we call it task-based language learning. Is it really easier to learn a language in a modern classroom? There are numerous factors which can affect the language learning process and we will name a few: general motivation of students, the way a language is taught- individually or in a group with a teacher and additional resources, the characteristics of the teacher, textbook and materials which are used, the time spent on studying, age of students, previous experience in language learning, talent, etc. Despite the fact that a language can be learned completely free of charge online, students still claim that the role of teacher is important and that their success depends a lot on the teacher's skills. Both traditional and modern teachers have the role of not only someone who transfers knowledge, but someone who also evaluates their work, leads them, educates them and motivates them. The teacher should be motivated, enthusiastic, tolerant, compassionate, fun, creative, always ready to gain new skills. Also, what affects the learning process is the attitude of students toward the language, the teacher, the culture and the course.

The teacher's knowlegde of course content, as well as the teaching method, contribute a lot to students' achievements [5]. It is also stated that the teacher's flexibility and creativity play an important role in this process. In other words, that means the teacher can easily adapt to their students and their needs, and to make the class more interesting and innovative. Students are mostly motivated by the teacher who is also higly motivated and energetic. The teacher with great rethorics, body language and good interaction with students is certainly more successful than the one without these traits. The atmosphere of the group is also essential when learning a foreign language. The atmosphere should be friendly and relaxed, aimed at success, and not at mistakes. Real studying starts once students remove their anxieties. The teacher with authoritative attitude in teaching cannot achieve successful results, at least when it comes to foreign language teaching. Speaking and writing skills are reproductive skills which can only be acquired by active speaking or writing, which is why it is necessary for students to be active participants all the time, in order to memorize new words or practice new grammar units. Anxiety usually comes as the result of fear of failure. This mostly happens when the interaction with the teacher is inappropriate, i.e. when there is no mutual trust [6].

The main role of the teacher is to prepare students for permanent self-education [7]. No matter how long a foreign language is being studied, it can always be improved. Any language (mother tongue or a foreign language) is a life-long learning process with vocabulary that is constantly being expanded [8]. Furthermore, every student has their own memorizing techniques (repeating outloud), visualization (imagining situations), kinaesthetic (acting and movements), rewriting words, reading texts, watching movies etc.

\section{RESEARCH METHODOLOGY AND RESULTS}

As teachers, we all try to find the best way for our students to acquire a foreign language in every class and to respond to the needs of every type of student. However, for gaining meaningful results not only for this paper, but for our future classes as well, we have also decided to conduct a very brief empirical research with our students. Based on their answers, we will conclude if and how much modern classroom can accelerate and ease foreign language learning, as well as whether students find that there is a difference between ICT and traditional classroom and what that difference would be in their personal opinion. In this way, we will have an insight into students' motivation, ambitions and studying goals.

The research, conducted for the purpose of this paper, implies a quantitative analysis among 119 male and female students who study at Singidunum University in Belgrade, Serbia. More precisely, $53.8 \%$ of the interviewees study at Faculty of Business, whereas $45.5 \%$ of them study at Faculty of Tourism and Hospitality Management, and $0.8 \%$ of the examinees are students of Faculty of Technical Sciences. When it comes to the year of their studies, the highest percentage (46.9\%) are the second year, $32.8 \%$ of them are in their first year of studies, $11 \%$ of them are third year students, and 5.9\% are at their final year of studying. All students who participated in the research study the English language (119), and they can choose the German language (34) and the Spanish language (22) as their second foreign language. There 
are also other elective language courses at Singidunum University, but we have chosen German and Spanish as they cover the highest number of students.

Table 1

\begin{tabular}{cccc}
\hline \multirow{2}{*}{$\begin{array}{c}\text { Number of } \\
\text { students }\end{array}$} & \multicolumn{3}{c}{ Foreign Language } \\
\cline { 2 - 4 } & English & German & Spanish \\
\hline & 119 & 34 & 22 \\
\hline
\end{tabular}

The instrument used for this study was an online, anonymous questionnaire which students were asked to fill in during their foreign language (English, German, and Spanish) classes. The form of questionnaire was Google online questionnaire form. Prior to being given the questionnaire, students were asked in an informal discussion whether they are familiar with the concept of ICT and we can conclude that they are not at all acquainted with this official term, though they are quite aware of the concept of the usage of online tools in the classroom. The questions given to students were multiple-choice questions and they could choose only one answer per question. In other words, questions were closed-ended. Only the questions about which language the interviewees study had more than one answer, as all students at Singidunum University can study at least two foreign languages. For most questions that were statements about ICT or traditional classrooms, students had the following answers to choose: strongly agree, agree, disagree, and strongly disagree.

The overall results of the questionnaire show that students, $80.3 \%$ of them, are certain that ICT should be used in the classroom, although a small percentage, $19.7 \%$ of them think it is a waste of time. On the other hand, $91.6 \%$ of the interviewees find the Internet to be an essential tool for learning any language and they claim they use it for the same purpose on a daily basis. Almost the same percentage of the interviewed students answered positively to the question if they use the Internet to consult language topics. From 119 responses, $92.4 \%$ of them use the Internet in order to question language topics, while only $7.6 \%$ do not consult the Internet when they need an answer to a language topic. The next question that was significant was about how often they used their smartphones, tablets or laptops in language classes. Only $8.4 \%$ of students answered that they always use their mobile devices in language classes, and only $3.3 \%$ responded that they never use them. The most of them, $46.7 \%$ and $41.8 \%$ replied that they rarely or often use them in the language classroom, respectively.
What might be a surprise is their answer to the question 'Do you prefer to practice foreign language with a textbook and workbook or with your computer and Internet?' as almost $50 \%$ of them said they preferred a textbook and workbook, which is a form of a traditional teaching method. Furthermore, the same percentage may be applied when answering the question: 'Can you imagine your language class without the use of ICT?', where $51.6 \%$ of students answered "yes", which leads us to the conclusion that, although they think ICT should be used in the classroom, they still prefer the traditional, or "old- fashioned" way of teaching and studying, highly valuing the teacher's lectures and explanations in classroom. We must add that we have received the same comment from our students verbally, while we were discussing these issues during our regular classes. They do not expect their language teacher to use ICT tools during each class if there is not a clear, teaching and learning purpose behind their use. Consequently, for question 'Are a teacher's lectures, presentations and explanations more effective than the use of ICT tools for language learning?' $64.7 \%$ of the students answered that they agree, and $27 \%$ strongly agree, while only $6.6 \%$ students disagree and $1.6 \%$ strongly disagree.

Table 2 .

\begin{tabular}{ccc}
\hline \multirow{2}{*}{ Answers } & $\begin{array}{c}\text { Are a teacher's lectures and explanations } \\
\text { more effective than the use of ICT tools } \\
\text { for language learning? }\end{array}$ \\
\cline { 2 - 3 } & Strongly agree & Agree \\
\hline 33 & 79 \\
\hline
\end{tabular}

One of the question in the questionnaire was whether students learn more effectively in traditional or contemporary classroom, where $64 \%$ of students chose ICT classroom. Furthermore, we have also asked our students whether how much modern and well-equipped classroom can motivate students to learn a foreign language. Around $60 \%$ of students claim that this would be a great motivation source for them.

Table 3.

\begin{tabular}{ccc}
\hline \multirow{2}{*}{ Answers } & \multicolumn{2}{c}{$\begin{array}{c}\text { Do you find it easier to learn language } \\
\text { with ICT tools? }\end{array}$} \\
\cline { 2 - 3 } & Yes & No \\
\hline & 112 & 10 \\
\hline
\end{tabular}


We have to agree that modern generations enjoy using the Internet, smart phones, tablets and other modern means not only in their free time and not only for pleasure, but for studying as well. Students from older generations could not possibly imagine online learning or using some Internet resources for studying as it would damage their sight, unable highlighting the main and most important points, and it would not include the mere sound of turning the pages or carrying their precious books with them. The newer generations are accustomed to this type of studying. For them, traditional learning, which is not followed by some videos, visual illustrations or similar applications, can sometimes be very boring and demanding. Therefore, we should ask ourselves whether there is a chance for old, traditional classroom to become obsolete in modern world, due to the constant usage of ICT? At this point, these two learning types are intertwined and the best solution would be to use them both, which is also the main argument of our students and interviewees. To be more precise, $77 \%$ of students claim that the usage of ICT in the classroom has a very positive effect on their attendance. We should be aware of the fact that, due to the online era in which we can do anything we want via the Internet, students' attendance is constantly decreasing. Nowadays, even when it comes to learning, there is a special distance-learning program for students and online materials and various resources. However, the statement that ICT contributes to students' attendance at such point is most certainly a positive one.

Table 4.

\begin{tabular}{ccc}
\hline \multirow{2}{*}{ Answers } & \multicolumn{2}{c}{$\begin{array}{c}\text { Is it necessary to use ICT tools in the } \\
\text { language classroom? }\end{array}$} \\
\cline { 2 - 3 } & Yes & No \\
\hline & 98 & 24 \\
\hline
\end{tabular}

When it comes to various online resources used in modern classroom, the interviewees state that they prefer watching videos (46\%), using their smart phones (23\%) - for an online language game, spell check, vocabulary check etc; using online dictionaries (17\%) and using their laptops (13\%).

Therefore, as we have previously supposed, what our student actually need and what actually is the best option for learning a foreign language is a combination of both traditional and ICT approach, as all students would benefit from what they find to be more appropriate for their language acquisition.
Table 5.

\begin{tabular}{ccc}
\hline \multirow{2}{*}{ Answers } & \multicolumn{2}{c}{$\begin{array}{c}\text { Can you imagine your language class } \\
\text { without the use of ICT? }\end{array}$} \\
\cline { 2 - 3 } Yes & No \\
\hline 60 & 59 \\
\hline
\end{tabular}

\section{CONCLUSION}

If we analyze the difference between ICT and traditional classroom in theory and in practice, we will most certainly find numerous differences. Moreover, if we ask students and teachers about their opinion regarding these issues, we will get diverse answers as well. To be more precise, in theory, it has been believed by teachers that ICT is a more desirable approach for students in modern language classroom, even though teachers themselves are more likely to prefer traditional teaching methods. In practice, students find ICT not to be an essential, but just an additional and optional part of language learning process, whereas traditional materials such as textbooks and workbooks are still a very useful tool that helps them acquire a foreign language, regardless of which language that is. In other words, what we as teachers think students might want and need from our lectures in the classroom is not just the usage of ICT and definitely not the usage of ICT in every class, but a mixture of both ICT and traditional learning/ teaching methods. Furthermore, when it comes to certain language aspects, students actually prefer the old, traditional tools such as textbooks and workbooks.

In contemporary education and, more specifically, in the foreign language classroom, it is essential to stimulate developing of speaking skills and communication skills. The integration of students' speaking, listening, reading and writing skills in each class, supported with ICT, are highly valued by new pedagogies. This combination can stimulate students' motivation for both language learning and improvement of their language skills. If there is no appropriate pedagogy of the language teacher behind the use of ICT in classroom, language teaching and learning process is not possible to be functional and effective. On the other hand, the mere usage of traditional methods in the form of simple usage of textbooks and workbooks cannot be successful any more. Therefore, in order to be effective foreign language teachers, we, as teachers, must comply with both modern tendencies and students' demands, even when these two are completely juxtaposed, especially if this affects their motivation and class attendance, let alone 
their results in language learning and their acquisition of language skills. In other words, we should combine the advantages and benefits of both traditional and ICT approach in our classrooms, while maintaining the role of educators, mediators and at the same time recognizing the needs of our students which, as we have seen in this research, do not necessarily have to comply with modern tendencies in education. When asked whether we would rather use traditional classroom or ICT classroom, our answer should depend firstly on our students' skills, needs and motivation. Only then will we be able to achieve our goals as successful foreign language teachers.

\section{REFERENCES}

[1] Z. Bozu, P. J. Canto Herrera, El profesorado universitario en la sociedad del conocimiento: competencias profesionales docentes, Revista de Formación e Innovación Educativa Universitaria, Vol. 2, No 2, pp 87-97, 2009

[2] M. Veljković Michos, L. Petronić Petrović, Necessary Step From "ICT" to "LTK" in Foreign Language Teaching and Learning, Sinteza 2016, International Scientific Conference on ICT and E-Business Related Research, Belgrade, Singidunum University, Serbia, pp 321-325, 2016
[3] M. A. Zabalza, Competencias docentes del profesorado universitario. Calidad y desarrollo profesional, Madrid, Narcea, pp 71-168, 2003

[4] A. H. Rinaldi, La red - guías de usuario y netiqueta, 1997

[5] S. Simić Šašić, I. Sorić, Pridonose li osobne karakteristike nastavnika vrsti interakcije koju ostvaruju sa svojim učenicima, Društvena istraživanja: Časopis za opća društvena pitanja 19, pp 973-994, 2010

[6] S. Simić Šašić, I. Sorić, Kvalitet interakcije nastavnikučenik: povezanost s komponentama samoreguliranog učenja, ispitnom anksioznošću i školskim uspehom, Suvremena psihologija 14, pp 35-55, 2011

[7] K. Lasić, Uloge nastavnika u tradicionalnoj i kvalitetnoj školi, Putokazi 3, pp 101-110, 2015

[8] T. Bagić, Samostalnost u učenju stranih jezika i zajednički europski referentni okvir za jezike, Život i škola 27, pp 222-233, 2012 